\title{
Presence of pathogenic bacteria in ice cubes and evaluation of their survival in different systems
}

\author{
Luca Settanni $^{1} \cdot$ Raimondo Gaglio $^{1}$ (D) $\cdot$ Carlo Stucchi $^{2} \cdot$ Simone De Martino ${ }^{2}$. \\ Nicola Francesca ${ }^{1} \cdot$ Giancarlo Moschetti $^{1}$
}

Received: 15 September 2017 / Accepted: 7 November 2017 / Published online: 18 November 2017

(C) Springer-Verlag GmbH Germany, part of Springer Nature and the University of Milan 2017

\begin{abstract}
In this study, 60 samples of ice cubes produced at different levels (domestic, restaurant and industrial facilities), within a restricted geographical area, were investigated for their general microbiological characteristics through the analysis of populations other than enteric bacteria. Total mesophilic bacteria were in the range $1.01 \times 10^{2}-9.55 \times 10^{3}$, $3.12 \times 10^{2}-6.31 \times 10^{3}$ and $1.30 \times 10^{2}-3.99 \times 10^{3} \mathrm{CFU} /$ $100 \mathrm{~mL}$ of thawed ice from domestic freezer (DF), stock boxes (SB) for self-production performed with ice machines in bars and pubs, and from sales packages (SP) of industrial productions, respectively. Some DF and SP samples were negative for the presence of total psychrotrophic bacteria, showing that there are no specific microbial groups associated with ice. Pseudomonads were found in the majority of ice samples analyzed. The levels of contamination of the ice samples were significantly different among the three ice cube production levels. The samples produced at domestic level and those collected from bars and pubs were characterised by the highest cell densities. The colonies representative for the different bacterial morphologies were randomly picked up from plates, purified to homogeneity and subjected to the phenotypic and genotypic characterisation. Fifty-two strains representing 31 species of eight bacterial genera were
\end{abstract}

Electronic supplementary material The online version of this article (https://doi.org/10.1007/s13213-017-1311-1) contains supplementary material, which is available to authorized users.

Raimondo Gaglio

raimondo.gaglio@unipa.it

1 Dipartimento Scienze Agrarie, Alimentari e Forestali, Università di Palermo, Viale delle Scienze 4, 90128 Palermo, Italy

2 Istituto Nazionale Ghiaccio Alimentare (INGA), via di Capo le Case 3, 00187 Rome, Italy identified, with the most numerous groups included in Pseudomonas, Staphylococcus, Bacillus and Acinetobacter. A consistent percentage of the microorganisms identified from ice are known agents of human infections, and their presence indicate an environmental contamination. In order to evaluate the effectiveness of the ice cubes to transfer pathogenic agents to consumers, a bar consumption was simulated with different drink systems added with ice cubes artificially contaminated with the strains found at dominant levels (Acinetobacter lwoffii ICE100, Bacillus cereus ICE170, Pseudomonas putida ICE224 and Staphylococcus haemolyticus ICE182), and the results showed a consistent reduction of bacterial risk due to alcohol, $\mathrm{CO}_{2}, \mathrm{pH}$ and antibacterial ingredients of vodka, whisky, Martini, peach tea, tonic water and coke.

Keywords Cross-contamination - Genetic identification . Human infections $\cdot$ Hygiene $\cdot$ Ice cubes $\cdot$ Microbial survival

\section{Introduction}

The worldwide industrial production of ice cubes for human consumption, namely "food grade ice" or simply "food ice", is on the increase. The current production of ice packed in bags and commercialised is estimated at around 500,000 t/year in Europe and 5,600,000 t/year in the United States ( $)$. Stucchi, oral communication). The Packaged Ice Quality Control Standards manual published by the International Packaged Ice Association provides the quality and processing standards for packaged ice produced by its members. However, the quality and safety of packaged ice products is not consistent (Lee et al. 2017). Due to several hygiene issues related to direct (used for cooling drinks) or indirect (used for cooling fish soon after catching) ice consumption that led to the occurrence of gastroenteritis (Graman et al. 1997; Wilson et al. 1997; 
Nichols et al. 2000; Pawsey and Howard 2001; Falcao et al. 2004; Lateef et al. 2006; Gerokomou et al. 2011; Noor Izani et al. 2012), the industrial manufacturing of ice cubes still has to undergo high process standards (Hampikyan et al. 2017). The general flow diagram for ice cube production applied at industrial level, indicating the critical points related to the microbiological contaminations, is reported in Fig. 1.

However, a consistent production of ice cubes occurs by ice cube maker machines (self-production) and is strictly intended for direct consumption, especially in bars, pubs and restaurants (Gaglio et al. 2017). Since food ice is a product obtained through the freezing of potable water, the presence of intestinal bacteria is an indicator of the hygienic status of the ice (Lateef et al. 2006; Ukwo et al. 2011). The analysis of food ice produced in countries with high hygiene standards revealed the presence of classes of microorganisms that compromise the drinkability of water (Nichols et al. 2000; Gerokomou et al. 2011; Awuor et al. 2016; Lee et al. 2017). In particular, Gaglio and co-workers (2017) recently investigated the presence of enteric bacteria in several samples of ice cubes produced at different (industrial, restaurant and home) levels, evidencing a consistent presence of undesired species with the dominance of members of Enterococcus, Stenotrophomonas and Pantoea genera.

In general, the analyses of microorganisms associated with ice samples collected follow a standard approach based on microbiological counts and the application of biochemical tests for the identification of major pathogenic agents such as Escherichia coli, Salmonella spp., Yersinia spp., Pseudomonas aeruginosa, Clostridium perfringens, Shigella spp., Vibrio cholerae and Aeromonas spp. (Nichols et al. 2000; Falcao et al. 2002; Gerokomou et al. 2011; Noor Izani et al. 2012; Awuor et al. 2016; Hampikyan et al. 2017). The presence of other undesired opportunistic pathogenic species is not commonly investigated, although food ice is responsible for the dissemination of clinically relevant bacteria (Gaglio et al. 2017).

Based on the above considerations, the aim of the present work was to: (1) evaluate the presence and levels of total mesophilic and psychrotrophic bacteria, as well as pseudomonads of food ice produced at home-, restaurant- and industrylevel; (2) perform phenotypic and genotypic characterisation of the isolates found at the highest cell densities; and (3) monitor the survival of representative strains in different alcoholic beverages and soft drinks.

\section{Materials and methods}

\section{Ice collection}

Three different production levels were investigated for the presence of bacteria in food ice. The ice samples were collected from domestic freezers (DF) for home-level production, from stock boxes (SB) for self-production performed with ice machines in bars and pubs, and from sales packages (SP) for the productions performed by industrial ice facilities. Five ice productions per typology (DF1-DF5, SB1-SB5, SP1SP5) were sampled in duplicate at a 2-month interval for a total of 60 ice samples, which were transferred into sterile stomacher bags and transported in a thermal insulated box. All producers were located within the Palermo province (Sicily, Italy) and transformed the water supplied by the municipal source.

\section{Microbiological analyses}

Approximately $500 \mathrm{~g}$ of each ice sample, corresponding to 25-50 ice cubes (considering that, depending on the shape, the individual ice cube weight ranged from $10 \mathrm{~g}$ to $20 \mathrm{~g}$ ) were thawed in a 1-L sterile Dhuram bottle at room temperature, and a volume of $100 \mathrm{~mL}$ per each microbial group was subjected to membrane filtration. The microbiological investigation included the following bacterial groups: total mesophilic bacteria (TMB) on plate count agar, incubated at $30{ }^{\circ} \mathrm{C}$ for $72 \mathrm{~h}$; total psychrotrophic bacteria (TPB) on plate count agar, incubated at $7{ }^{\circ} \mathrm{C}$ for 7 days; and pseudomonads on Pseudomonas agar base supplemented with $10 \mathrm{mg} / \mathrm{mL}$ cetrimide fucidin, incubated at $25{ }^{\circ} \mathrm{C}$ for $48 \mathrm{~h}$. When the number of colonies exceeded 186 , corresponding to the number of squares present on the membrane grid, aliquots of $1 \mathrm{~mL}$ from each sample were inoculated directly into agar media. All media and supplements were purchased from Oxoid (Milan, Italy).

\section{Isolation and phenotypic characterisation of ice bacteria}

Colonies of bacteria developed on agar media were randomly picked up for each morphology (color, margin, surface and elevation). Almost five identical colonies (or fewer if five were not available or showed confluent growth) were collected from the agar plates. All bacterial cultures were subjected to the purification phase, verified by an optical microscope, after several consecutive subcultures on the same media and under the same growth conditions as those used for plate counts.

A preliminary phenotypic characterisation was applied on the pure bacterial isolates propagated in nutrient broth (Oxoid). The KOH test (Gregersen 1978) was performed to determine the type of cell wall. The catalase test was carried out by addition of $\mathrm{H}_{2} \mathrm{O}_{2}(5 \%$, w/v) to the colonies. Cell morphology and motility were evaluated by microscopic inspection. The formation of spores was investigated as follows: cell suspensions of pure cultures were treated at $85^{\circ} \mathrm{C}$ for $15 \mathrm{~min}$ and, subsequently, inoculated in the same media used for 
Fig. 1 General flow diagram of industrial packaged ice cube production. Adapted from INGA (2015). CP Critical point, $C C P$ critical control point, $U V$ ultraviolet

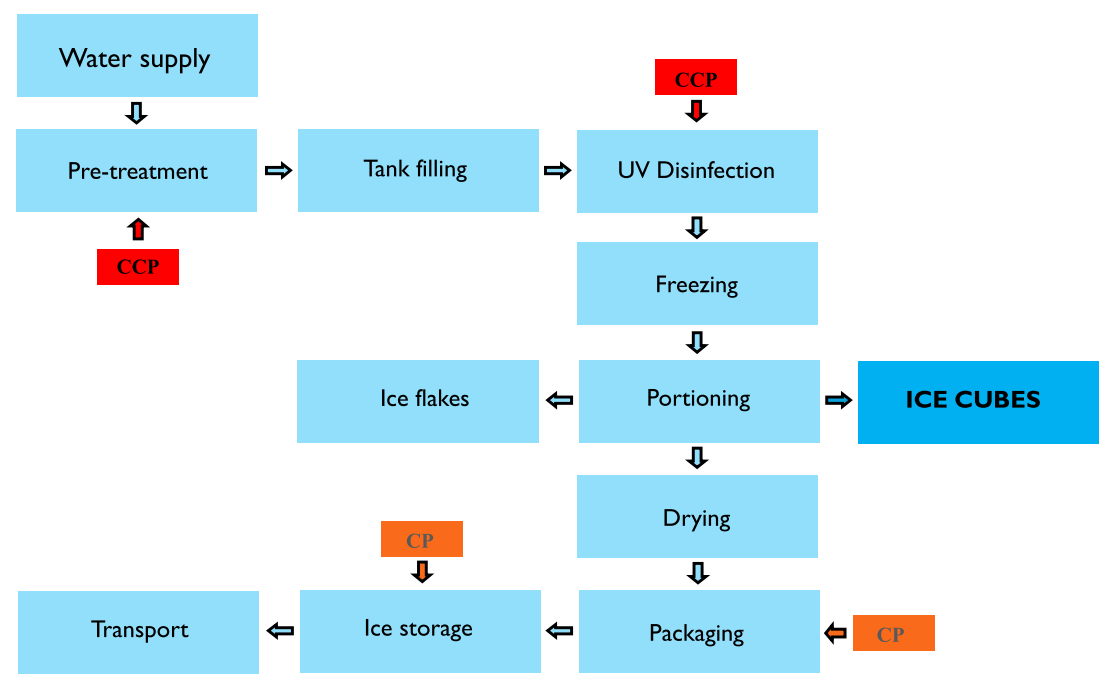

isolation and purification and incubated under optimal growth conditions.

\section{Bacterial strain typing and identification}

DNA was extracted from cells by lysis, applying the Instagene Matrix kit (Bio-Rad, Hercules, CA) following the manufacturer's instructions, after overnight growth in nutrient broth at $30{ }^{\circ} \mathrm{C}$. DNA concentration was adjusted to $25 \mathrm{ng} / \mu \mathrm{L}$ before being used as a template for PCR.

Differentiation of bacteria at strain level was performed by random amplification of polymorphic DNA (RAPD)-PCR using three primers (M13, AB111, and AB106), while identification at species level was performed by $16 \mathrm{~S}$ rRNA gene sequencing with the primer pair $\mathrm{fD} 1 / \mathrm{rD} 1$. The methodology applied for the genetic characterisation was previously described by Settanni et al. (2012). The sequences of the 16S rRNA gene fragment were compared with those available in the EzTaxon-e (http://eztaxon-e.ezbiocloud.net/) database, which compares a given sequence to those of type strains only.

\section{Survival assays}

The survival test was performed with the bacteria found at the highest levels for the most numerous groups. These microorganisms were first cultivated under optimal growth conditions and then washed twice in Ringer's solution (Sigma-Aldrich, Milan, Italy), after centrifugation at $5000 \mathrm{~g}$ for $5 \mathrm{~min}$. The cells were suspended in autoclaved $\left(121^{\circ} \mathrm{C}\right.$ for $\left.20 \mathrm{~min}\right)$ still mineral water (Terme di Geraci Siculo S.p.a., Geraci Siculo, Italy) at the highest concentrations found in the samples analyzed, and the contaminated water was used to produce ice cubes (at $-32{ }^{\circ} \mathrm{C}$ ) containing a single bacterial species using autoclaved stainless steel ice cube trays. After plate counts, the levels of the artificial contamination of the ice cube was ca.
$3.00 \times 10^{2} \mathrm{CFU} / 100 \mathrm{~mL}$ t.i. for $A$. lwoffii ICE100, ca. $9.00 \times$ $10^{3} \mathrm{CFU} / 100 \mathrm{~mL}$ t.i. for $B$. cereus ICE170, ca. $4.00 \times 10^{2}$ $\mathrm{CFU} / 100 \mathrm{~mL}$ t.i. for $P$. putida ICE224 and ca. $4.00 \times 10^{3}$ CFU/100 mL t.i. for S. haemolyticus ICE182.

The concentrations of microorganisms were followed in beverages and drinks characterised by different $\mathrm{pH}$, alcohol volume, sugar content and presence or absence of $\mathrm{CO}_{2}$. To this purpose, the following systems were used: vodka (Keglevich, Plzen, Czech Republic), as an alcoholic (38\% vol) neutral (pH 6.0) beverage; whisky (Jack Daniel's, Lynchburg, Tennessee), as an alcoholic (40\% vol) acidic ( $\mathrm{pH} 4.2)$ beverage; Martini (Martini and Rossi, SpA, Pessione, Italy) as a moderate alcoholic (14.4\%, $\mathrm{pH} 3.8)$ beverage; peach tea (Conad, Fruttagel SCpA, Alfonsine, Italy) as a sugary (9.7\% w/v, pH 3.3) drink; tonic water (Kinley, Sesto S. Giovanni, Italy) and coke (Coca Cola Italia Srl, Sesto S. Giovanni, Italy) as sugary (9.4 and $10.6 \mathrm{w} / \mathrm{v}$, respectively) acidic ( $\mathrm{pH} 2.8$ and 2.7 , respectively) carbonated drinks. The simulation of drink contamination occurred through addition of artificially inoculated ice cubes (corresponding to $60 \mathrm{~mL}$ ) to $100 \mathrm{~mL}$ of each drink in $200 \mathrm{~mL}$ volume sterile cups (Anicrin, Scorzé, Italy). All contaminated systems were left at room temperature until complete ice thawing and then analyzed, depending on the inoculation level, by membrane filtration or plate count. Ringer's solution (Oxoid) was used as control. Three independent experiments were carried out on three different days.

\section{Statistical analysis}

Microbiological data were subjected to one-way analysis of variance (ANOVA). Pair comparison of treatment means was achieved by Tukey's procedure at $P<0.05$. Differences among the production levels (domestic, restaurant and industrial) were evaluated using the generalised linear model (GLM) procedure. 


\section{Results}

\section{Microbial loads}

The results of the microbiological levels of the ice samples were expressed as colony forming units (CFU)/100 mL of thawed ice (t.i.) and are presented in Table 1. The differences among the ice cubes within each production level were statistically significant for the three groups of microorganisms object of investigation. The highest levels of microorganisms were detected on PCA incubated at $30^{\circ} \mathrm{C}$. TMB were detected in all samples, and their densities were in the range $1.01 \times$ $10^{2}-9.55 \times 10^{3}, 3.12 \times 10^{2}-6.31 \times 10^{3}$ and $1.30 \times 10^{2}-3.99 \times$ $10^{3} \mathrm{CFU} / 100 \mathrm{~mL}$ t.i. for DF, SB and SP ice cubes, respectively. In general, TPB were estimated at lower levels than mesophilic bacteria, with the highest numbers $\left(9.60 \times 10^{2}\right.$ CFU/100 mL t.i.) found in SP2 samples. Furthermore, three DF (DF1-DF3) and two SP (SP3 and SP4) samples were negative for the presence of TPB. Pseudomonads were detected in all DF samples, but the highest levels were registered for the samples SB1 $\left(3.90 \times 10^{2} \mathrm{CFU} / 100 \mathrm{~mL}\right.$ t.i. $)$ and SP2 $(3.84 \times$ $10^{2} \mathrm{CFU} / 100 \mathrm{~mL}$ t.i.). It is worth noting that the samples showing the highest TMB levels were also characterised by high levels of the other two microbial groups. In particular, sample SP2 showed consistent numbers of colonies on all three media.

Regarding the three production systems (DF, SB and SP), the statistical analysis resulting from their interaction indicated that the microbial levels were significantly different only for TPB.

\section{Phenotypic grouping of bacteria}

After enumeration, the colonies of bacteria representative of all different morphologies present in plates were collected from agar media and purified before microscopic inspection and preliminary biochemical characterisation. Among the 1113 bacteria isolated, this approach allowed recognition of six groups (Table 2). Both Gram positive and Gram negative bacteria were differentiated in three groups. Five different cell morphologies were observed, with straight rods included in the Groups I and VI. All bacterial groups were positive in the catalase test. The majority of bacteria were non-motile. The ability to generate endospores was investigated for rods, and was displayed only by the bacteria included in Group I. The most numerous group was Group VI, which included more than $32 \%$ of total isolates.

\section{Strain differentiation and identification of bacteria}

Almost $50 \%$ of all bacterial cultures of each phenotypic group was analyzed by RAPD-PCR in order to perform strain typing. As reported in the dendrograms (Figs. S1 and S2), the combination of the three RAPD patterns of each isolate showed that the cultivable bacterial community associated to the ice cubes analyzed in this study was composed of 32 Gram positive (Fig. S1) and 20 Gram negative (Fig. S2) strains.

The 52 strains were identified by sequencing of the $16 \mathrm{~S}$ rRNA gene, and were allotted to eight genera: five for Gram positive (Fig. S1) and three for Gram negative (Fig. S2) bacteria. The most numerous genera were Pseudomonas, including 13 strains representing nine species (Fig. S2), Staphylococcus, including 13 strains representing three species (Fig. S1), and Bacillus, including 12 strains representing nine species (Fig. S1), followed by Acinetobacter with six strains of four species (Fig. S2) and Brevibacterium with four strains of two species (Fig. S1). The total diversity of bacteria that survived in the ice samples analyzed was quite wide, since 31 species were identified (Ac. No. KX588553-KX588574, KX $588580-\mathrm{K} X 588582$, KX 588588 -KX588601, KX588603-KX588615).

\section{Distribution of bacterial species}

The distribution of bacterial species among the ice samples was also investigated. Table 3 shows that the highest biodiversity was found in samples produced at domestic level (16 species). The diversity, in terms of number of different species, revealed for SB and SP samples was almost comparable (12 and 10 species, respectively). Regarding the distribution of the most numerous groups, Bacillus species were mostly represented in DF samples, Staphylococcus in SB samples and Pseudomonas in both of these productions. It is worth noting that only the sample SP4 hosted Pseudomonas in the ice cubes produced at industrial level, although SP2 and SP3 were also positive for the growth of colonies on PAB. In fact, those bacteria were identified as Acinetobacter, showing a low specificity of PAB medium for Pseudomonads. The highest presence of Acinetobacter (Acinetobacter guillouiae and Acinetobacter haemolyticus) was detected in sample SP2.

\section{Bacterial survival in beverages and drinks}

The bacteria chosen to perform the survival tests were A. lwoffii ICE100, B. cereus ICE170, P. putida ICE224 and $S$. haemolyticus ICE182, which were the strains found at the highest levels among the corresponding groups (IV, I, VI and III, respectively). The results of survival tests are reported in Fig. 2. All bacteria remained at constant levels in Ringer's solution, while different behaviour was registered for the six liquid systems considered. In general, all systems determined a statistical significant reduction of the number of cells inoculated through ice addition. In particular, the most drastic effect on the cell viability was displayed by whisky, from which no colony developed and, except 
Table 1 Microbial load ${ }^{\mathrm{a}}$ of ice cubes produced at different levels. Results indicate mean values \pm $\mathrm{SD}$ of four microbiological counts (carried out in duplicate for two independent sample collections). Data within a column followed by the same letter are not

significantly different according to Tukey's test. $D F$ Domestic freezer, $S B$ stock boxes, $S P$ sales packages, $n . d$. not detected, $P A B$ Pseudomonas agar base for pseudomonads

\begin{tabular}{|c|c|c|c|}
\hline \multirow[t]{2}{*}{ Ice sample } & \multicolumn{3}{|l|}{ Medium $^{\mathrm{b}}$} \\
\hline & PCA $30^{\circ} \mathrm{C}$ & PCA $7{ }^{\circ} \mathrm{C}$ & PAB \\
\hline DF1 & $1.78 \times 10^{2} \pm 3.90 \times 10^{\mathrm{B}}$ & n.d. & $1.00 \pm 0.80^{\mathrm{A}}$ \\
\hline DF2 & $1.01 \times 10^{2} \pm 2.60 \times 10^{\mathrm{A}}$ & n.d. & $4.03 \times 10 \pm 3.40^{\mathrm{C}}$ \\
\hline DF3 & $6.20 \times 10^{3} \pm 8.10 \times 10^{2} \mathrm{D}$ & n.d. & $1.85 \times 10^{2} \pm 1.58 \times 10^{\mathrm{E}}$ \\
\hline DF4 & $9.55 \times 10^{3} \pm 1.42 \times 10^{3} \mathrm{E}$ & $4.01 \times 10^{2} \pm 3.08 \times 10^{\mathrm{B}}$ & $1.95 \times 10 \pm 7.20^{\mathrm{B}}$ \\
\hline DF5 & $2.03 \times 10^{3} \pm 4.52 \times 10^{2 \mathrm{C}}$ & $2.10 \times 10^{2} \pm 13.5 \times 10^{\mathrm{A}}$ & $1.60 \times 10^{2} \pm 1.29 \times 10^{D}$ \\
\hline Statistical significance & $* * *$ & $* * *$ & $* * *$ \\
\hline SB1 & $3.12 \times 10^{2} \pm 1.10 \times 10^{2} \mathrm{~B}$ & $9.90 \times 10 \pm 1.91 \times 10^{2} \mathrm{D}$ & $3.90 \times 10^{2} \pm 2.07 \times 10^{\mathrm{E}}$ \\
\hline SB2 & $2.18 \times 10^{2} \pm 6.70 \times 10^{\mathrm{A}}$ & $3.25 \times 10 \pm 2.90^{\mathrm{B}}$ & n.d. \\
\hline SB3 & $1.21 \times 10^{3} \pm 2.70 \times 10^{2 \mathrm{C}}$ & $2.23 \times 10 \pm 5.30^{\mathrm{E}}$ & $2.80 \pm 0.50^{\mathrm{B}}$ \\
\hline SB4 & $6.31 \times 10^{3} \pm 8.83 \times 10^{2} \mathrm{E}$ & $3.56 \times 10^{2} \pm 2.23 \times 10^{\mathrm{F}}$ & $2.20 \times 10^{2} \pm 2.41 \times 10^{2} \mathrm{D}$ \\
\hline SB5 & $2.10 \times 10^{3} \pm 1.83 \times 10^{2} \mathrm{D}$ & $9.10 \times 10 \pm 3.9^{\mathrm{C}}$ & $5.80 \pm 1.00^{\mathrm{C}}$ \\
\hline Statistical significance & $* * *$ & $* * *$ & $* * *$ \\
\hline SP1 & $3.30 \times 10^{2} \pm 4.37 \times 10^{\mathrm{D}}$ & $3.03 \times 10 \pm 6.1^{\mathrm{C}}$ & n.d. \\
\hline SP2 & $3.99 \times 10^{3} \pm 4.51 \times 10^{2} \mathrm{E}$ & $9.60 \times 10^{2} \pm 5.34 \times 10^{\mathrm{D}}$ & $3.84 \times 10^{2} \pm 2.60 \times 10^{\mathrm{D}}$ \\
\hline SP3 & $3.17 \times 10^{2} \pm 3.43 \times 10^{\mathrm{C}}$ & n.d. & $1.13 \times 10 \pm 2.1^{\mathrm{B}}$ \\
\hline SP4 & $1.30 \times 10^{2} \pm 2.70 \times 10^{\mathrm{A}}$ & n.d. & $3.93 \times 10 \pm 4.6^{\mathrm{C}}$ \\
\hline SP5 & $1.81 \times 10^{2} \pm 2.69 \times 10^{\mathrm{B}}$ & $1.08 \times 10 \pm 4.4^{\mathrm{B}}$ & n.d. \\
\hline Statistical significance & $* * *$ & $* * *$ & $* * *$ \\
\hline $\begin{array}{l}\text { Interaction among the } \\
\text { production levels } \\
(\mathrm{DF} \times \mathrm{SB} \times \mathrm{SP})\end{array}$ & NS & $*$ & NS \\
\hline
\end{tabular}

$* P \leq 0.05, * * P \leq 0.01, * * * P \leq 0.001$, NS not significant

${ }^{\mathrm{a}} \mathrm{CFU} / 100 \mathrm{~mL}$ of thawed ice

${ }^{\mathrm{b}} \mathrm{PCA} 7{ }^{\circ} \mathrm{C}$, plate count agar incubated at $7{ }^{\circ} \mathrm{C}$ for total psychrotrophic microorganisms; PCA $30^{\circ} \mathrm{C}$, plate count agar incubated at $30^{\circ} \mathrm{C}$ for total mesophilic microorganisms for A. lwoffii ICE100, tonic water. Compared to the other systems, vodka allowed the highest persistence of A. lwoffii ICE100, P. putida ICE224 and $S$. haemolyticus ICE182, while the cell number of $B$. cereus ICE170 in this system was almost superimposable on that found in peach tea. The presence of viable cells in peach tea was found for all four strains, even though their levels were lower than those registered in vodka for three bacteria except B. cereus. Martini allowed a little survival of both Gram positive strains. $P$. putida ICE224 and B. cereus ICE170 disappeared from coke, while $A$. lwoffii ICE100 and $S$. haemolyticus ICE182 were found at very low levels.

\section{Discussion}

In this study, a polyphasic cultural approach consisting of microbiological counts, colony isolation, phenotypic
Table 2 Phenotypic grouping of bacteria isolated from ice cubes. $n$ Number of isolates, n.d. not determined

\begin{tabular}{|c|c|c|c|c|c|c|}
\hline \multirow[t]{2}{*}{ Characteristic } & \multicolumn{6}{|l|}{ Groups } \\
\hline & $\begin{array}{l}\text { I } \\
(n=252)\end{array}$ & $\begin{array}{l}\text { II } \\
(n=90)\end{array}$ & $\begin{array}{l}\text { III } \\
(n=231)\end{array}$ & $\begin{array}{l}\text { IV } \\
(n=162)\end{array}$ & $\begin{array}{l}\mathrm{V} \\
(n=18)\end{array}$ & $\begin{array}{l}\text { VI } \\
(n=360)\end{array}$ \\
\hline $\begin{array}{l}\text { Cell } \\
\text { morphology }\end{array}$ & $\begin{array}{l}\text { Straight } \\
\text { rod }\end{array}$ & Short rod & $\begin{array}{l}\text { Coccus } \\
\quad \text { (cluster) }\end{array}$ & $\begin{array}{l}\text { Coccoid } \\
\text { rod }\end{array}$ & $\begin{array}{l}\text { Curved } \\
\text { rod }\end{array}$ & Straight rod \\
\hline Gram reaction & Positive & Positive & Positive & Negative & Negative & Negative \\
\hline Catalase test & Positive & Positive & Positive & Positive & Positive & Positive \\
\hline Motility & - & - & - & - & + & + \\
\hline Spore formation & + & - & n.d. & - & - & - \\
\hline
\end{tabular}


Table 3 Speciographic distribution of bacteria among ice samples: A. Acinetobacter; B. Bacillus; Br. Brevibacterium; L. Lysinibacillus; M. Microbacterium; Ps. Pseudomonas; $P \times$. Pseudo $\times$ anthomonas; $S$. Staphylococcus

\begin{tabular}{|c|c|c|c|c|c|c|c|c|c|c|c|c|c|c|c|}
\hline \multirow[t]{3}{*}{ Species } & \multicolumn{15}{|c|}{ Ice samples } \\
\hline & \multicolumn{5}{|c|}{ Domestic level } & \multicolumn{5}{|c|}{ Bars/Pubs } & \multicolumn{5}{|c|}{ Industries } \\
\hline & DF1 & DF2 & DF3 & DF4 & DF5 & SB1 & SB2 & SB3 & SB4 & SB5 & SP1 & $\mathrm{SP} 2$ & SP3 & SP4 & SP5 \\
\hline A. guillouiae & & & & & & & & & & & & - & & & \\
\hline A. haemolyticus & & & & & & & & & & & & - & & & \\
\hline A. johnsonii & & घ & & & & & & & ! & ! & & & & & \\
\hline A. lwoffii & & & & & & & & & & & & & - & & \\
\hline B. aerophilus & & & - & & & & & & & & & & & & \\
\hline B. cereus & & - & & & & & & & & & & & & & \\
\hline B. isronensis & & & & & & & & & & & & & घ & & \\
\hline B. licheniformis & - & & & & - & - & & & & & & & & & \\
\hline B. megaterium & & & & & & & & & & & & & & & - \\
\hline B. nealsonii & & & - & & & & & & & & & & & & \\
\hline B. sonorensis & ! & & & & & & ! & & & & & & & & \\
\hline B. thuringiensis & & & & & & & & & & & & घ & & & \\
\hline B. toyonensis & & & & & - & & & & & & & & & & \\
\hline Br. frigoritolerans & & & & & & & & & & & - & & & & - \\
\hline Br. halotolerans & & & & & & - & & - & & & & & & & \\
\hline L. fusiformis & & & & - & & & & & & & & & & & \\
\hline L. halotolerans & & & & & - & & & & & & & & & & \\
\hline M. proteolyticum & & & & & & & & & & & & - & & & \\
\hline Ps. azotoformans & & & & & & & & & & & & & & - & \\
\hline Ps. baetica & & & & & & & & a & & & & & & & \\
\hline Ps. fragi & & & & घ & & & & & - & & & & & & \\
\hline Ps. granadensis & - & & & & & & & & & & & & & & \\
\hline Ps. japonica & & & & - & & & & & & & & & & & \\
\hline Ps. jessenii & & & & & & & & - & & & & & & & \\
\hline Ps. libanensis & & & & & & & & - & & & & & & & \\
\hline Ps. poae & & & & & - & & & & - & & & & & & \\
\hline Ps.putida & & & & घ & & & & & & & & & & & \\
\hline$P \times$. japonensis & & & & & & & & & & घ & & & & & \\
\hline S. epidermidis & & & & & & & & घ & घ & & & & & & \\
\hline S. haemolyticus & & & घ & & & & & & & & & & & & \\
\hline S. warneri & & & - & ! & & & & घ & घ & - & - & ! & ! & ! & \\
\hline
\end{tabular}

grouping and genetic strain differentiation followed by identification was applied to investigate on the viable bacteria hosted in food ice. Since the presence of pathogenic microorganisms in ice cubes is due not only to the contamination of the water used (Lateef et al. 2006; Northcutt and Smith 2010), to the scarce hygienic conditions during production and improper handling (Noor Izani et al. 2012), but also depends on the packaging containers or bags (Chavasit et al. 2011), the microbiological parameters of ice cubes were investigated for production carried out at three different levels, including small volume (home-made), medium volume (restaurant level) and high volume (industrial level) facilities. So far, no work has been carried out to evaluate the presence of specific psychrophilic bacteria associated to the matrix "ice". Due to the psychrotrophic characteristics of 

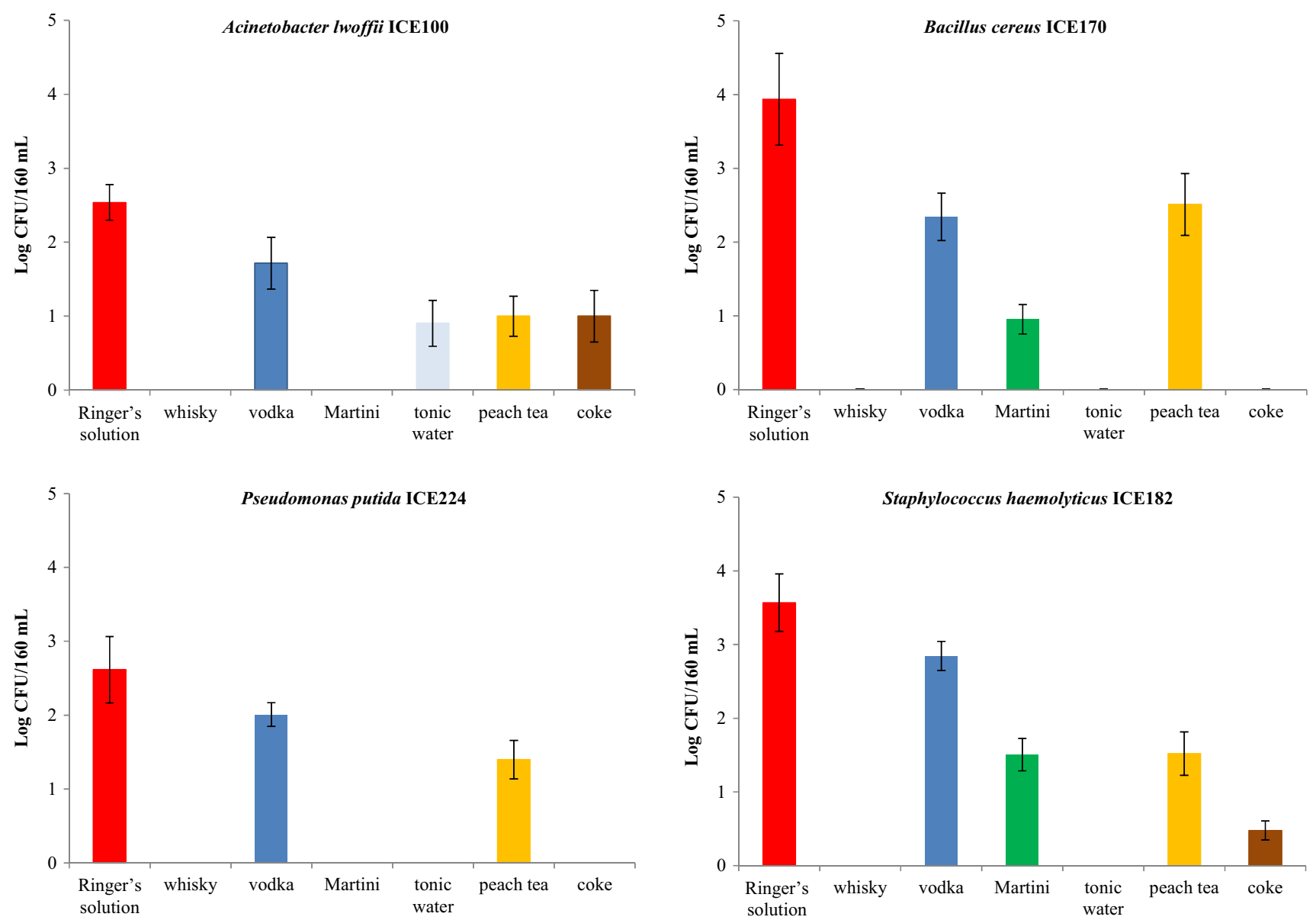

Fig. 2 Monitoring of dominating Gram positive and Gram negative bacteria of food ice in different alcoholic beverages and soft drinks

Pseudomonas and their ubiquity in food-related matrices and water, this bacterial group was the subject of our investigation.

Microbiological counts were carried out onto PCA, ass indicated for colony counts by the Council Directive 98/83/EC "on the quality of water intended for human consumption" (Commission Regulation, 1998), but the incubation was performed at $7{ }^{\circ} \mathrm{C}$ and $30{ }^{\circ} \mathrm{C}$ in order to specifically detect psychrotrophic and mesophilic bacteria, respectively, and onto PAB for the Pseudomonas group. The levels of these groups were estimated by the membrane filtration method followed for water analysis. Despite the high numbers of TMB, which were above $1 \times 10^{2} \mathrm{CFU} / 100 \mathrm{~mL}$ t.i. in all samples, and within the limits of Council Directive 98/83/EC, surprisingly, the levels of TPB of three home-made and two industrially processed samples were below the detection limit. Pseudomonads were detected in almost all samples, since only samples SB2, SP1 and SP5 showed no colony growth.
The phenotypic grouping and the genetic investigation showed that the major groups of strains were Pseudomonas, Staphylococcus, Bacillus and Acinetobacter. Staphylococci were also found at a high percentage $(34 \%)$ of the on-site packaged ice samples produced in South California analyzed by Lee et al. (2017), and in $19.42 \%$ of flake ice samples used for fish preservation analyzed by Economou et al. (2017). Economou et al. (2017) also detected Pseudomonas spp. in $24.10 \%$ of ice samples. To our knowledge, there are no previous works describing the presence of Bacillus spp. and Acinetobacter spp. in ice cubes.

Regarding the Staphylococcus species found in this study, although all strains identified belonged to the group of coagulase-negative staphylococci (CNS), S. epidermidis has become an important cause of nosocomial infections. This bacterium colonises the skin and mucous membranes of the human body (Vuong and Otto 2002). Other CNS species frequently isolated from humans are Staphylococcus 
haemolyticus, an opportunistic pathogen related to implanted medical devices (Fredheim et al. 2009), and Staphylococcus warneri, which causes bacteremia in adult and paediatric patients (Kamath et al. 1992).

Infections by Acinetobacter represent an emerging threat to human health (Visca et al. 2011). Hospital outbreaks have been attributed mainly to Acinetobacter baumannii, but nosocomial infections caused by other species of this genus, including A. guillouiae, A. haemolyticus, Acinetobacter johnsonii and A. lwoffii, although rare and restricted to catheter-related bloodstream infections, have been reported (Wisplinghoff et al. 2004). Most of Acinetobacter species identified in this study are isolated from human skin and/or soil (A. lwoffii, A. johnsonii and A. guillouiae), while A. haemolyticus is mainly isolated from human specimens (Visca et al. 2011).

Among the nine Bacillus species identified from the ice isolates, only $B$. cereus is an important human pathogen (Kotiranta et al. 2000). All these Bacillus species can be considered as environmental contaminants, because they are commonly associated with soil (Palmisano et al. 2001), facilities (Venkateswaran et al. 2003) and cryotubes for collecting air (Shivaji et al. 2006, 2009). The other species identified from food ice samples, including all pseudomonads, brevibacteria, lysinobacilli, Microbacterium proteolyticum and Pseudoxanthomonas japonensis, are of environmental origin and do not generally represent a risk for humans. Regarding the primary source of contamination, only Pseudomonas baetica, Pseudomonas putida (Altinok et al. 2006; López et al. 2012), Pseudomonas jessenii (Verhille et al. 1999) and Pseudomonas libanensis (Dabboussi et al. 1999) can be considered aquatic bacteria. Thus, the bacterial contamination of food ice can be environmental, faecal contamination, or by greywater. These results support the statement of Lee et al. (2017) that an enforcement of processing standards during the on-site packaging of ice is needed.

The most common mode of consumption of ice cubes is through their direct addition to drinks and beverages, thus the potential risk associated with the transfer of the microbial load hosted in ice was also evaluated in this study. Tests were carried out recently, as reported by Gaglio et al. (2017), in drink/beverage systems containing different levels of alcohol, $\mathrm{CO}_{2}, \mathrm{pH}$ and antibacterial ingredients. The most lethal effect on the cell viability of $A$. lwoffii, $B$. cereus, $P$. putida and $S$. haemolyticus was registered for whisky. On the contrary, vodka allowed the highest persistence of all four strains tested. This result is not surprising, since a similar behaviour was previously displayed by enterobacteria and attributed to the neutral $\mathrm{pH}$ of vodka (Gaglio et al. 2017). All strains survived in peach tea, although their levels were lower than those registered in Ringer's solution (control trial). Martini killed Gram negative and allowed a residual survival of Gram positive bacteria. Regarding carbonated drinks, tonic water showed a stronger effect than coke, probably due to its quinine content-a known bactericidal compound (Kharal et al. 2009).

\section{Conclusions}

The results of this study showed that, besides the major bacterial groups that compromise the potability of water, other potentially pathogenic bacteria can be vectored by ice. As previously found for enteric bacteria (Gaglio et al. 2017), the three production systems (home-made, restaurant and industrial) analyzed are characterised by significantly different levels of contamination, with ice cubes collected from bars and pubs showing the highest cell densities of the strains representing risks for humans. Food ice was contaminated mainly by environmental sources, but faecal microorganisms and microorganisms transferred from greywater were also detected. A bar consumption was simulated, with different drink systems, in order to estimate the effectiveness of the ice cubes to transfer pathogenic agents to consumers, and the results indicated a consistent risk reduction due to alcohol, $\mathrm{CO}_{2}, \mathrm{pH}$ and antibacterial ingredients. Thus, although several studies have been conducted in the last 2 years on the microbiological quality of packaged food ice (Awuor et al. 2016; Economou et al. 2017; Gaglio et al. 2017; Hampikyan et al. 2017; Lee et al. 2017), focussing deep attention on the quality of water and transformation process, this study provides evidence and deepens previous findings (Gaglio et al. 2017) on the effective risk related to the most common mode of consumption of contaminated ice. Furthermore, the findings evidenced several criticisms related to the food ice cube production, indicating the need to better investigate the hygiene of the water and equipment used, the transformation process applied, and storage/transport conditions.

Acknowledgement This work was financed by the National Institute of Food Ice (INGA), Rome, Italy.

\section{References}

Altinok I, Kayis S, Capkin E (2006) Pseudomonas putida infection in rainbow trout. Aquaculture 261:850-855. https://doi.org/10.1016/j. aquaculture.2006.09.009

Awuor L, Thompson S, Thompson B, Liberda EN, Meldrum R (2016) Microbiological quality and handling practices of ice served in selected downtown Toronto food premises. Environ Health Rev 59: 83-87. https://doi.org/10.5864/d2016-017

Chavasit V, Sirilaksanamanon K, Phithaksantayothin P, Norapoompipat Y, Parinyasiri T (2011) Measures for controlling safety of crushed ice and tube ice in developing country. Food Control 22:118-123. https://doi.org/10.1016/j.foodcont.2010.05.016

Commission Regulation (1998) No 98/83/EC of 3 November 1998 on the quality of water intended for human consumption. Off J Eur Union 330:32-54 
Dabboussi F, Hamze M, Elomari M, Verhille S, Baida N, Izard D, Leclerc H (1999) Pseudomonas libanensis sp. nov., a new specie isolated from Lebanese spring waters. Int J Syst Bacteriol 49:1091-1101. https://doi.org/10.1099/00207713-49-3-1091

Economou V, Gousia P, Kemenetzi D, Sakkas H, Papadopoulou C (2017) Microbial quality and histamine producing microflora analysis of the ice used for fish preservation. J Food Saf 37:12285. https://doi. org/10.1111/jfs. 12285

Falcao JP, Dias AMG, Correa EF, Falcao DP (2002) Microbiological quality of ice used to refrigerate foods. Food Microbiol 19:269 276. https://doi.org/10.1006/fmic.2002.0490

Falcao JP, Falcao DP, Gomes TAT (2004) Ice as a vehicle for diarrheagenic Escherichia coli. Int J Food Microbiol 91:99-103. https://doi.org/10.1016/S0168-1605(03)00327-1

Fredheim EGA, Klingenberg C, Rohde H, Frankenberger S, Gaustad P, Flægstad T, Sollid JE (2009) Biofilm formation by Staphylococcus haemolyticus. J Clin Microbiol 47:1172-1180. https://doi.org/10. 1128/JCM.01891-08

Gaglio R, Francesca N, Di Gerlando R, Mahony J, De Martino S, Stucchi C, Moschetti G, Settanni L (2017) Enteric bacteria of food ice and their survival in alcoholic beverages and soft drinks. Food Microbiol 67:17-22. https://doi.org/10.1016/j.fm.2017.04.020

Gerokomou V, Voidarou C, Vatopoulos A, Velonakis E, Rozos G, Alexopoulos A, Plessas S, Stavropoulou E, Bezirtzoglou E, Demertzis PG, Akrida-Demertzi K (2011) Physical, chemical and microbiological quality of ice used to cool drinks and foods in Greece and its public health implications. Anaerobe 17:351-353. https://doi.org/10.1016/j.anaerobe.2011.06.005

Graman PS, Quinlan GA, Rank JA (1997) Nosocomial legionellosis traced to a contaminated ice machine. Infect Control Hosp Epidemiol 18:637-640

Gregersen T (1978) Rapid method for distinction of gram-negative from gram-positive bacteria. Appl Microbiol Biotechnol 5:123-127. https://doi.org/10.1007/BF00498806

Hampikyan H, Bingol EB, Cetin O, Colak H (2017) Microbiological quality of ice and ice machines used in food establishments. J Water Health 15:410-417. https://doi.org/10.2166/wh.2017.159.

Istituto Nazionale Ghiaccio Alimentare (2015) Manuale di corretta prassi operativa per la produzione di ghiaccio alimentare. In: http://www. ghiaccioalimentare.it/il-manuale/. Accessed 13 May 2017

Kamath U, Singer C, Isenberg HD (1992) Clinical significance of Staphylococcus warneri bacteremia. J Clin Microbiol 30:261-264

Kharal SA, Hussain Q, Ali S (2009) Quinine is bactericidal. J Pak Med Assoc 59:208-212

Kotiranta A, Lounatmaa K, Haapasalo M (2000) Epidemiology and pathogenesis of Bacillus cereus infections. Microbes Infect 2:189-198. https://doi.org/10.1016/S1286-4579(00)00269-0

Lateef A, Oloke JK, Kana EBG, Pacheco E (2006) The microbiological quality of ice used to cool drinks and foods in Ogbomoso metropolis, southwest, Nigeria. Internet J Food Saf 8:39-43

Lee KH, Ab Samad LS, Lwin PM, Riedel SF, Magin A, Bashir M, Vaishampayan PA, Lin WJ (2017) On the rocks: microbiological quality and microbial diversity of packaged ice in Southern California. J Food Prot 80:1041-1049. https://doi.org/10.4315/ 0362-028X.JFP-16-295

López JR, Diéguez AL, Doce A, De la Roca E, De la Herran R, Navas JI, Toranzo AE, Romalde JL (2012) Pseudomonas baetica sp. nov., a fish pathogen isolated from wedge sole, Dicologlossa cuneata (Moreau). Int J Syst Evol Microbiol 62:874-882. https://doi.org/ 10.1099/ijs.0.030601-0.
Nichols G, Gillespie I, de Louvois J (2000) The microbiological quality of ice used to cool drinks and ready-to-eat from retail and catering premises in the United Kingdom. J Food Prot 63:78-82. https://doi. org/10.4315/0362-028X-63.1.78

Noor Izani NJ, Zulaikha AR, Mohamad Noor MR, Amri MA, Mahat NA (2012) Contamination of faecal coliforms in ice cubes sampled from food outlets in Kubang Kerian, Kelantan. Trop Biomed 29:71-76

Northcutt JK, Smith D (2010) Microbiological and chemical analyses of ice collected from a commercial poultry processing establishment. Poult Sci 89:145-149. https://doi.org/10.3382/ps.2009-00205

Palmisano MM, Nakamura LK, Duncan KE, Istock CA, Cohan FM (2001) Bacillus sonorensis sp. nov., a close relative of Bacillus licheniformis, isolated from soil in the Sonoran Desert, Arizona. Int J Syst Evol Microbiol 51:1671-1679. https://doi.org/10.1099/ 00207713-51-5-1671

Pawsey RK, Howard P (2001) Drinking ice as a vector for gastrointestinal disease. Brit Food J 103:253-263. https://doi.org/10.1108/ 00070700110391380

Settanni L, Di Grigoli A, Tornambé G, Bellina V, Francesca N, Moschetti G, Bonanno A (2012) Persistence of wild Streptococcus thermophilus strains on wooden vat and during the manufacture of a Caciocavallo type cheese. Int J Food Microbiol 155:73-81. https:// doi.org/10.1016/j.jijfoodmicro.2012.01.022

Shivaji S, Chaturvedi P, Suresh K, Reddy GSN, Dutt CBS, Wainwright M, Narlikar JV, Bhargava PM (2006) Bacillus aerius sp. nov., Bacillus aerophilus sp. nov., Bacillus stratosphericus sp. nov. and Bacillus altitudinis sp. nov., isolated from cryogenic tubes used for collecting air samples from high altitudes. Int J Syst Evol Microbiol 56:1465-1473. https://doi.org/10.1099/ijs.0.64029-0

Shivaji S, Chaturvedi P, Begum Z, Pindi PK, Manorama R, Padmanaban DA, Shouche YS, Pawar S, Vaishampayan P, Dutt CB, Datta GN, Manchanda RK, Rao UR, Bhargava PM, Narlikar JV (2009) Janibacter hoylei sp. nov., Bacillus isronensis sp. nov. and Bacillus aryabhattai sp. nov., isolated from cryotubes used for collecting air from the upper atmosphere. Int J Syst Evol Microbiol 59:2977-2986. https://doi.org/10.1099/ijs.0.002527-0

Ukwo SP, Ndaeyo NU, Udoh EJ (2011) Microbiological quality and safety evaluation of fresh juices and edible ice sold in Uyo metropolis, south-south, Nigeria. Internet J Food Saf 13:374-378

Venkateswaran K, Kempf M, Chen F, Satomi M, Nicholson W, Kern R (2003) Bacillus nealsoni sp. nov., isolated from a spacecraftassembly facility, whose spores are $\gamma$-radiation resistant. Int J Syst Evol Microbiol 53:165-172. https://doi.org/10.1099/ijs.0.02311-0

Verhille S, Baida N, Dabboussi F, Izard D, Leclerc H (1999) Taxonomic study of bacteria isolated from natural mineral waters: proposal of Pseudomonas jessenii sp. nov. and Pseudomonas mandelii sp. nov. Syst Appl Microbiol 22:45-58

Visca P, Seifert H, Towner KJ (2011) Acinetobacter infection - an emerging threat to human health. IUBMB Life 63:1048-1054. https://doi. org/10.1002/iub.534

Vuong C, Otto M (2002) Staphylococcus epidermidis infections. Microbes Infect 4:481-489

Wilson IG, Hogg GM, Barr JG (1997) Microbiological quality of ice in hospital and community. J Hosp Infect 36:171-180

Wisplinghoff H, Bischoff T, Tallent SM, Seifert H, Wenzel RP, Edmond MB (2004) Nosocomial bloodstream infections in US hospitals: analysis of 24,179 cases from a prospective nationwide surveillance study. Clin Infect Dis 39:309-317. https://doi.org/10.1086/421946 